\title{
Az orvosmeteorológia történeti áttekintése - új horizont a preventív medicina területén
}

\author{
Boussoussou Nora dr. - Boussoussou Melinda dr. - Nemes Attila dr.
}

Semmelweis Egyetem, Általános Orvostudományi Kar, Érsebészeti Tanszék, Budapest

Jellemünk megismerésével párhuzamosan meg kell ismerni
testünk természetét is ... az anyag, melyböl készült,
rokonságot tart a földdel, a vizzel és a csillagokkal is:
a testben van valami örök...”
Márai Sándor

\begin{abstract}
Munkánk az orvosmeteorológia tudománytörténeti bemutatása, amelynek célja az, hogy felhívjuk a figyelmet az orvosmeteorológia tudományterületére. Az orvosmeteorológia, sajnos, kevésbé alkalmazott szakterület az orvosok mindennapi gyakorlatában. Azonban a klímaváltozás századunk legnagyobb, új egészségügyi kihívása, amely több milliárd embert érint és tesz ki nagyobb morbiditási és mortalitási veszélynek. A meteorológiai faktorok rizikótényező hatásának ismerete új prevenciós stratégiák kialakítását teszi lehetővé, amelynek segítségével csökkenthető a globális klímaváltozás által okozott meteorológiai tényezők negatív egészségügyi hatása. A jövőben az orvosmeteorológia új horizontot tárhat fel a preventív medicina területén. A globális klímaváltozás negatív hatásai ellen való harcban az egészségügyi szakembereknek kell élen járniuk. Ahhoz, hogy az orvosmeteorológia valóban a preventív medicina elfogadott részévé váljon, nemcsak a „tanokat, hanem a tanok történetét is ismernünk kell”. Orv. Hetil., 2017, $158(5), 187-191$.
\end{abstract}

Kulcsszavak: orvosmeteorológia, tudománytörténeti áttekintés, atmoszférikus paraméterek, preventív medicina, globális klímaváltozás, cardiovascularis rizikótényezők

\section{Historical overview of medical meteorology - the new horizon in medical prevention}

The aim of this article is to draw attention to the medical meteorology from the perspective of the history of science. Unfortunately medical meteorology is not part of the daily medical practice. The climate change is a new challenge for health care worldwide. It concerns millions of people a higher morbidity and mortality rate. Knowing the effects of the meteorological parameters as risk factors can allow us to create new prevention strategies. These new strategies could help to decrease the negative health effects of the meteorological parameters. Nowadays on the field of the medical prevention the medical meteorology is a new horizon and in the future it could play an important role. Health care professionals have the most important role to fight against the negative effects of the global climate change.

Keywords: medical meteorology, historical overview, atmospheric parameters, preventive medicine, global climate change, cardiovascular risk factor.

Boussoussou, N., Boussoussou, M., Nemes, A. [Historical overview of medical meteorology - the new horizon in medical prevention]. Orv. Hetil., 2017, 158(5), 187-191.

(Beérkezett: 2016. november 3.; elfogadva: 2016. december 8.) 
„Az ember a természettől függ, de a természet is függ tôle. A természet alkotta ót, o" pedig átalakitja a természetet." Anatole France e sora az egyik legszebb irodalmi megfogalmazása lehetne a 2009-es Lancet Bizottság jelentése által megállapított ténynek, amely szerint a XXI. század legnagyobb egészségügyi kihívása a klímaváltozás [1]. A klímaváltozás különböző természeti katasztrófákat okozó hatása egyértelmű. Az 1960-as évek óta, a WHO 2009-es felmérése alapján, megháromszorozódott a természeti katasztrófák előfordulási aránya [2]. Mindemellett azonban ezek az extrém és kedvezőtlen meteorológiai szituációk erősen befolyásolják az egészségi állapotot is. Napjainkban a légkörrel kapcsolatos szindróma (ARS) egyre nagyobb előfordulási arányt mutat. Mindazon fizikális, mentális, szociális jóllét állapotának változásával és/vagy betegségek kialakulásával, illetve súlyosbodásával járó állapotok, amelyek egyértelmúen kapcsolatba hozhatóak időjárásfüggő légköri változásokkal, légkörrel kapcsolatos szindrómaként határozhatóak meg [3]. Tekintettel arra, hogy a globális klímaváltozás egyre inkább érzékelteti hatását, egyre gyakoribbak az extrém éghajlati események, az ARS-szindróma (atmosphere-related syndrome) különböző kórképeket kiváltó hatása miatt, századunk legújabb és talán egyik legnagyobb kihívást jelentő kórképe. Ezáltal a különböző atmoszférikus paraméterváltozások egészségügyi hatásainak vizsgálata kiemelt jelentőségú szereppel bír. A lokális klímaváltozásra vonatkozó egészségügyi kutatások fontosak ahhoz, hogy országspecifikus egészségügyi prevenciós stratégiák kidolgozására legyen lehetőség. Magyarországon az ezzel kapcsolatos, legtöbb kórképre vonatkozó és legnagyobb esetszámra kiterjedő kutatásokat a Semmelweis Egyetem Érsebészeti Tanszékén végezzük. Vizsgálataink során egyértelmúen bizonyítható volt különböző atmoszférikus paraméterek minor cardiovascularis rizikótényező hatása $[4,5]$. Jelen cikknek azonban nem az eddigi kutatási eredmények bemutatása a célja. „Homines eruditi non solum dogmata, sed historiam dogmatum amant." (A müvelt emberek nemcsak a tanokra, hanem a tanok történetére is kiváncsiak.) - A cikk e vezérgondolata mentén az orvosmeteorológia történetének a bemutatása a cél.

Leibniz, a XVI. században élő német polihisztor monadologiatana szerint az univerzumot felépítő monászok (jelentése: egység) közötti kapcsolat eleve elrendezett harmónia [6]. Világunk egy rendszer, amelyben a különböző egységek szoros kapcsolatban állnak és hatnak egymásra. Leibniz tanát a természettudományokra is vonatkoztathatjuk, amelyből következően a különböző természeti hatások szoros kapcsolatban állnak az emberi szervezet fiziológiás és patofiziológiás változásaival. Leibniz szerint ahhoz, hogy ezzel kapcsolatos új ismeretekhez jussunk, a „fiziológia azon múvészetét kell alkalmaznunk, amely során a természetet magát kell kikérdeznünk, s mintegy kínpadra vonnunk". A polihisztor tudós, Ramonazzival folytatott levelezésében olvasható, hogy Leibniz fontosnak tartotta és szorgalmazta az egészségügyi helyzet és az időjárási viszonyok összefüggéséról éves orvosi jelentések készítését [7]. Leibniz munkásságának egyik jelentős üzenete, hogy a medicina a tapasztalatban és az empíriában éri el a csúcsát.

Ennek az üzenetnek a gondolata már Mezopotámiában is jelen volt. Mezopotámiából, Kr. e. 3000-ből, ismertek már olyan orvosi elóírások, amelyek figyelembe vették az időjárási változásokat. Az egyik legősibb elbeszélő költemény, a Gilgames-eposz, hét gonosz széljárásról tesz említést, amely betegséget és lázat okoz [8].

Az első megfigyeléseken alapuló orvosmeteorológiai vizsgálatok a hagyományos kínai orvoslás tevékenységi körében figyelhetőek meg. Huang Ti, a történetírásban csak Sárga Császárnak nevezett uralkodó, rendeletet adott ki arra vonatkozóan, hogy minden egészségi állapotot befolyásoló időjárási adatot fel kell jegyezni. Ezek az első orvosmeteorológiával kapcsolatos feljegyzések a Kr. e. 2600-as évekből származnak. A kínai orvoslásra jellemző holisztikus szemlélet tükrében, az emberi szervezet múködését az azt körülvevő környezeti tényezőkkel való összefüggésben elemezték, így az időjárási tényezők patofiziológiás hatásait is megfigyelték. A Sárga Császár klasszikus belgyógyászati alapkönyvében (Kr. e. 500-300 közötti időszakban) részletes leírást olvashatunk az időjárási tényezők hatásairól. A taoizmus alapjai is hordoznak orvosmeteorológiai megfigyeléseket. A jang a napsugár, forróság, szárazság jelképe, ezzel szemben a jin a sötétség, hideg és a nedves levegő. Megfigyelték, hogy amennyiben a szervezet kapcsolata nem megfelelő az időjárással, a jin-jang állapot egyensúlyvesztése következik be, amely szervi eltéréseket okoz. A kínai orvoslás szerint a különböző meteorológiai elemek (szél, hideg, forróság, nedvesség, szárazság, nyári forróság) különböző szervi eltéréseket okoznak. A tüdőre a szárazság, a szívre a hőség, a vesére a hideg, a lépre a nedvesség és a májra a szél hat [9].

$\mathrm{Az}$ ókori hippokratikus medicina nedvelmélete, az előbbiekhez hasonlóan, a szervezet változásait szintén a természeti környezet függvényeként határozza meg. A szelek a fekete epét szaporítják, a hő a vér mennyiségét, a hideg és nedves időjárás pedig a nyák mennyiségét [10].

$\mathrm{Az}$ arab orvoslás megfigyelései, amelyek jelentős alapul szolgáltak az európai orvoslás fejlődéséhez, szintén nagy jelentőséget tulajdonítanak a különböző meteorológiai hatásoknak. Ibn Sina (Avicenna) el Kanun fi Tib orvosi könyvében (Kánon) - amely Sir William Osler szerint a „legragyogóbb tankönyv, amit valaha írtak” az egészséget befolyásoló tényezőket két részre osztotta: „res naturales” és „res non naturales” hatásokra. Az időjárási viszonyok a „res non naturales” hatások közé tartoznak [11].

Tudománytörténetileg kiemelendő jelentőségű, hogy a kínai orvoslás alapjának tekinthető Sárga Császár klaszszikus belgyógyászati tankönyve mellett, a nyugati orvoslás alapját képező Corpus Hippocraticum, illetve az arab orvoslás el Kanun fi Tib nagy jelentőségű orvosi 
könyve is részletesen tárgyalja a meteorológiai tényezők szervezetre gyakorolt hatását.

A Sárga Császár könyvében a szél szervezetre gyakorolt hatására vonatkozóan az alábbi sorokat olvashatjuk: „100 betegséget a kóros szél okozza" [9]. Hippokratész: Peri tón aerón, hüdatón kai topón múvében a szélre vonatkozóan pedig a következő sorok szerepelnek: „Aki a gyógyító múvészetet helyesen akarja elsajátítani, annak a következőképpen kell eljárnia. Ezután figyelni kell a szelekre, a melegekre és hidegekre...” „Déli szelek megnehezítik a hallást, zavarossá teszik a szemet, elnehezítik a fejet, lomhává teszik a testet, petyhüdtté a végtagokat. Ha tehát déli szél uralkodik, a betegségekben ezeket a tüneteket kell elszenvedni. Ha viszont északi szél van, akkor köhögés, rekedtség, vizelési nehézségek, félelmi állapotok, a bordák fájdalma és mellkasi fájdalmak tapasztalhatók. Amidőn északi szél uralkodik, a betegségben ilyen zavarokra számíthatunk" [12].

A szövegrészletben szereplő „déli szelek” a meleg légáramlatot jelölhetik, amelyet ma melegfront néven határozunk meg, az „északi szél” pedig a hideg légáramlatnak megfeleltethető hidegfrontot jelöli. A front fogalom a Kr. e. V. században még nem volt ismert, azonban kiemelendő annak a felismerésnek a jelentősége, hogy bizonyos időjárási helyzetek, egyes betegségek és tünetek előfordulásának gyakoriságát emelik.

Ibn Sina Kánon könyvében szintén a szélre vonatkozóan a következő megfigyeléseket tárgyalja: A déli szél viszketegséget, epileptikus görcsöt és álmatlanságot okoz. A hideg levegő vértolódásokat, apoplexiát, paralitikus állapotot, továbbá náthát és köhögést idézhet elő. A meleg levegő általában lazítja, elernyeszti a testet. A vért a felületre vonja [13].

Annak ellenére, hogy teljesen eltérő klimatikus jellemzőkkel bíró területekről származó és eltérő kulturális háttérrel bíró művekről van szó, a nyugati, a keleti és az arab orvoslás megfigyelései ugyanolyan kóroktani következtetéseket vontak le a különböző időjárási tényezőkre vonatkozóan.

Arisztotelész (Kr. e. 384-322) négykötetes Meteorologica címú múvében vizsgálja az „ég és föld” közötti jelenségeket, az időjárás szervezetre gyakorolt hatását. A meteorológia kifejezés is innen származik, az „athmos” - lélegzet és „sphaira” - gömb szóösszetételből.

Néhány filozófus a természeti tényezők szervezetre gyakorolt hatását az időjáráson kívül már a bolygók vizsgálatára is kiterjesztette. Ptolemaiosz Tetrabiblosz múvében vizsgálja a bolygók és emberi szervezet állapota közötti kapcsolatot, Abdias Trew (1597-1669) pedig bolygókórtan-elméletében. Robert Fludd (1574-1637) szerint „Isten a betegségeket bolygók, csillagok, szelek angyalai útján teremti” [14].

A XVII. századtól az orvosmeteorológiára vonatkozóan már hippokratikus elméleti alapokon nyugvó, de egyre komolyabb megfigyeléseken alapuló eredmények jelentek meg.
Thomas Sydenham (1624-1689), akit „angol Hippokratész"-ként tart számon a történetírás, munkásságát már az orvosmeteorológiai adatok módszeres gyưjtése jellemzi. A különböző betegségek ontologikus-öntörvényűen keletkező kialakulását környezeti hatásoknak tulajdonította [15].

A bioklimatológia legnagyobb léptékű fejlődése a XIX. századra tehető. A klimatológia atyjának nevezett, a század legkiemelkedőbb neohippokratikus gondolkodójának tartott Marius Piéry (1873-1957) az 18531953 időszakot a „klimatológia századának” nevezte. Marius Piéry a Lyonban múködő orvosi egyetem orvosklimatológiai részlegét vezette [16]. Az, hogy az orvosmeteorológia már orvosi egyetem kerettanterv részeként szerepelt, mutatja a tudományterület egyre kiemelkedőbb jelentőségét.

A biometeorológiai kutatások új irányvonalát Jules Gavarret (1809-1890) francia orvos és statisztikus jelölte ki 1840-ben megjelent Principes généraux de statistique médicale címú múvében, amely szerint a kvalitatívhippokratikus leírás használhatatlan, az orvoslásnak a „gyönyörű Poisson-elméletet” kell alkalmaznia [17]. Az orvosi tudás statisztikai metódusokon kell, hogy alapuljon. Ettől kezdve az orvosmeteorológiai eredmények már statisztikailag is bizonyított eredmények.

Egymástól függetlenül, egyre több biometeorológiai kutatás kezdődött. Az 1800-as évek elején Johan Peter Frank (1745-1821) német belgyógyász elrendelte, hogy az összes orvos köteles időjárással kapcsolatos orvosi jelentést készíteni [18]. James R. Fleming a klímát tartotta az amerikai katonáknál megjelenő betegségek legfóbb okának, ezért 1820-ban az amerikai hadsereg orvosi részlegénél meteorológiai obszervációt rendelt el [19].

Henrich Collisen (1740-1824), a koppenhágai sebészeti akadémia professzora készítette az első különböző betegségekre vonatkozó orvosi topográfiai megfigyelést Dánia specifikus területi részeire vonatkozóan. Megfigyelései alapján a klímát találta a fóvárosban kialakuló betegségek major okának.

Több országot összefogó kutatás is megjelent, amelyben Kayser a szezonális mortalitást vizsgálta nyugat-európai országokban [20].

A humán bioklimatológia fogalma Alexander von Humbolt (1769-1859), a modern orvosmeteorológia megalapítójának munkásságából eredeztethető. A bioklimatológia a különböző légköri tényezők fiziológiás, illetve patofiziológiás hatásaival foglalkozó tudományág. Két részterületét különböztetjük meg. A légkör dinamikus folyamatainak hatására kialakuló biológiai reakciókkal a meteorobiológia, a légkör statikus hatásaival a klimatobiológia foglalkozik. E két tudományágon belül a meteoro- és klimatofiziológia az időjárás hatására szervezetben bekövetkező fiziológiás reakciókat vizsgálja, a meteoro- és klimatopatológia pedig a patológiás eltéréseket tárgyalja [21].

1956-ban Párizsban megalakult a Nemzetközi Biometeorológiai Társaság. A Nemzetközi Biometeorológiai 
Társaság 1996-os definíciója szerint a biometeorológia olyan interdiszciplináris tudomány, amely a különböző atmoszferikus folyamatok és az élővilág kapcsolatát vizsgálja [22]. Napjainkra a biometeorológia már önálló tudományág.

Magyarországon az első jelentős orvosmeteorológiai feljegyzéseket Benkő Sámuel (1743-1825) készítette. A Borsod vármegyei föorvos hatkötetnyi orvosmeteorológiai naplót jelentetett meg Ephemerides meteorologico-medicae címen. A múvek Közép-Európa első jelentős orvosmeteorológiai tanulmányai, amelyeket a kortárs tudósok német nyelvre is lefordítottak. Múveinek újszerüségét mutatja, hogy a korabeli tudományos felfogással ellentétben, amelyben a különböző diszciplínák kutatásai egymástól függetlenek voltak, Benkő egy múben és öszszefüggéseiben tárgyalta orvosi, csillagászati és meteorológiai megfigyeléseit. „Azon deák munkámban, mellyben egész tíz esztendők alatt az időnek és a Miskolczi levegóégnek változásit és az inkább uralkodó betegségeket feljegyzettem, s némelly eredendő betegségeknek is lételeket nyilvánvaló példákkal és tagadhatatlan tapasztalásokkal megmutattam." Az orvosmeteorológia mindennapi gyakorlatban való fontosságára is felhívta a figyelmet. A vármegyei fóorvos szerint a hadseregben képzett orvosoknak kell jelen lenni, akik az éppen esedékes évszakból előre megmondják, milyen betegség ütheti fel a fejét. Benkö Sámuel volt az első magyar tudós, aki az orvosmeteorológiát prevenciós diszciplínává avanzsálta [23].

A XIX. században orvosi értekezések is születtek e témakörben. Kamenszky István 1825-ben írta doktori értekezését „A magyarországi levegő egészséges létéről általányosan” címmel [24]. Történeti érdekesség, hogy az egyébként sebész- és szülészmesteri oklevelet szerzett Semmelweis Ignác (1818-1865) Tractatus de Vita Plantarum címú botanikai doktori értekezésében a légköri elektromosság biológiai jelentőségéről írt [25].

Az előzőekben már említett „gyönyörű Poisson-elmélet" alkalmazása, a biostatisztika alkalmazásának előtérbe kerülésével, az orvosmeteorológiai kutatásokhoz számítógépes modellezőrendszerek alkalmazása hatalmas szakmai előrelépést jelentett. Szintén tudománytörténeti érdekesség, hogy itt is fellelhetünk magyar vonatkozást. Neumann János döntése alapján a számítógép kísérleti felhasználása során a legnagyobb prioritást az időjáráselőrejelző modellek kapták. Az első ilyen előrejelzés Amerikában, a hadsereg számára készült, 1950-ben, az ENIAC (Electronic Numerical Integrator And Computer) számítógépen [26].

A magyar orvosmeteorológia legkiemelkedőbb alakjai Örményi Imre (1932-2003) és Kérdö István (19231981), akikre a magyar orvosmeteorológia atyjaiként tekinthetünk.

Kérdő István az Országos Reuma- és Fürdöügyi Intézetben dolgozott belgyógyász orvosként, ahol 1967-től a meteoro-klimatobiológiai osztály fóorvosa volt. Kutatásainak középpontjában leginkább a vegetatív idegrendszer múködésének vizsgálata állt, meteorológiai és belgyógyászati megközelítésben egyaránt. Munkatársaival kidolgozta a vegetatív index (V. I.) képletét, amelynek segítségével megállapítható az adott egyén geofizikai biotípusa. A képletben a diasztolés vérnyomás (D) és pulzusérték $(\mathrm{P})$ szerepelnek: V. I. $=(1-\mathrm{D} / \mathrm{P}) \times 100$.

A különböző atmoszférikus paramétereken belül érdeklődésének középpontjában a levegőionok hatásainak vizsgálata állt, amely kutatására levegőionizátort is szerkesztett [27].

Örményi Imre az ORFI orvosmeteorológusaként kezdte el a mindennapi orvosi tevékenységbe integrálni a humánmeteorológiát. Megfigyelései alapján az időjárásváltozáson belül a frontátvonulásokat tartotta a legjelentősebb atmoszférikus változásnak, amely a leginkább hatással van a szervezetre, ezáltal különböző betegségek kialakulására. Érdekesség, hogy az akkori Nehézipari Minisztériumhoz tartozó nagyvállalatok meteorológiai előrejelzéseket kértek a munkahelyi balesetek megelőzése érdekében. Kedvezőtlen meteorológiai paraméterek esetén szigorúbban ellenőrizték a munkavédelmi intézkedéseket és az arra érzékeny dolgozóknak több pihenést engedélyeztek. A különböző vállalatok anyagi támogatásukkal is szorgalmazták, hogy orvosmeteorológiai laboratórium jöhessen létre. A meteoroszenzitivitás megállapítására Kérdő és Örményi kérdőívet dolgoztak ki. Ennek hatására az 1970-es években a Péterfy Sándor Utcai Kórházban a hypertoniás és diabeteses betegekkel kitöltették ezt a kérdőívet, és bizonyos mütétek elvégzését a meteoroszenzitivitás mértékétől tettek függővé [28].

Hazánkban az első orvosmeteorológiai konferenciát 1963-ban Budapesten tartották.

Magyarországon jelenleg az orvosmeteorológia tudományterülete háttérbe szorult. Az Érsebészeti Tanszéken végzett kutatómunkánk egyik célja ennek a hiánynak a pótlása.

Az előbbiekben példaként felsorolt kutatások mutatják, hogyan kezdett a meteorológia az orvostudomány részévé válni, és hogyan vált napjainkra már teljes mértékben önálló tudományterületté. Az orvosmeteorológia története, több évszázaddal ezelőtti megállapításai még mai ismereteink fényében is megállják a helyüket. Kritikusan értékelve ezeket az ismereteket, korunkra átmentve sok régi megfigyelés hasznosítható és inspiráló a mai orvosmeteorológiai kutatások munkájában.

Napjainkban az orvosmeteorológia új horizontot tár fel a preventív medicina területén.

Anyagi támogatás: A cikk megírása anyagi támogatásban nem részesült.

Szerzôi munkamegosztás: B. N.: A kézirat szövegezése, a hipotézis kidolgozása, irodalomkutatás elvégzése. B. M.: A kézirat szövegezése, irodalomkutatás elvégzése, a hipotézis kidolgozása. N. A.: A kézirat lektorálása, szakmai véleményezése. A cikk végleges változatát valamennyi szerző elolvasta és jóváhagyta.

Érdekeltségek: A szerzőknek nincsenek érdekeltségeik. 


\section{Irodalom}

[1] Costello, A., Abbas, M., Allen, A., et al.: Managing the health ef fects of climate change. Lancet and University College London Institute for Global Health Commission. Lancet, 2009, 373(9676), 1693-1733.

[2] World Health Organization 2009 Available from: http://apps. who.int/iris/bitstream/10665/44246/1/9789241598880_ eng.pdf

[3] Von Mackensen, S., Hoeppe, P., Maarouf, A., et al.: Prevalence of weather sensitivity in Germany and Canada. Int. J. Biometeorol., 2005, 49(3), 156-166.

[4] Boussoussou, N., Boussoussou, M., Entz, L., et al.: Occurrence of acute cardiovascular diseases under different atmospheric parameters. [Akut cardiovascularis kórképek vizsgálata különböző légköri paraméterek tükrében.] Orv. Hetil., 2014, 155(27), 10781082. [Hungarian]

[5] Boussoussou, M., Boussoussou, N., Entz, L., et al.: The risks factors of cardiogenic thromboembolism: atmospheric parameters and atrial fibrillation. [A cardiogen thromboembolia kockázati tényezője: légköri paraméterek hatása korunk „cardiovasculáris járványára”, a pitvarfibrillációra.] Érbetegségek, 2015, 22(1), 13-17. [Hungarian]

[6] Leibniz, G. W.: Selected philosophical writings. [Gottfried Wilhelm Leibniz válogatott filozófiai írásai.] Európa Könyvkiadó, Budapest, 1986. [Hungarian]

[7] Schultheisz, E.: Leibniz and the medicine. [Leibniz és a medicina.] Semmelweis Kiadó és Multimédia Stúdió Kft., Budapest, 2013. [Hungarian]

[8] Rékas, S.: Gilgames. [Gilgames - Agyagtáblák üzenete.] Európa Könyvkiadó, Budapest, 1966. [Hungarian]

[9] Maoshing, N.: The Yellow Emperor's classic of medicine. Shambhala Publications, Boston, 1995.

[10] Kérdó, I.: Hippocrates and bioclimatology. [Hippokratész és a bioklimatológia.] Az Országos Orvostörténeti Könyvtár Közleményei, 1955. Available from: http://orvostortenet.hu/ tankonyvek/tk-05/pdf/2.3.3.1/1955_001_kerdo_istvan_hippokratesz_bioklimatologia.pdf [Hungarian]

[11] Abbort, M. E.: The evolution of modern medicine. Can. Med. Assoc. J., 1922, 12(3), 182-183.

[12] Kapferer, R.: Die Werke des Hippokrates. Die hippokratische Schriftensammlung in neuer deutscher Übersetzung. Hippokrates-Verlag, Stuttgart-Leipzig, 1934.

[13] Birtalan, Gy.: The Canon of Avicenna and the European medical science. [Avicenna „Kánon”-ja és az európai orvostudomány.] Ponticulus Hungaricus, 2013, 17(10). Available from: http:// members.iif.hu/visontay/ponticulus/rovatok/limes/ibn-szinakanon.html [Hungarian]
[14] Fludd, R.: Utriusque Cosmi Maioris Scilicet et Minoris Meta physica, Physica Atque Technica Historia, 1617.

[15] Dewhurst, K.: Thomas Sydenham (1624-1689) reformer of clinical medicine. Med. Hist., 1962, 6(2), 101-118.

[16] Besancenot, J. P.: La climatologie biologique et médicale en France: 1853-2003. Press. Therm. Climat., 2003, 140, 63-84.

[17] Huth, E.: Jules Gavarret's Principes Généraux de Statistique Médicale. J. R. Soc. Med., 2008, 101(4), 205-212.

[18] Withers, C. W.: Placing the enlightenment: thinking geographically about the age of reason. University of Chicago Press, Chicago, 2007.

[19] Fleming, J. R.: Meteorology in America, 1800-1870. Johns Hopkins Press, Baltimore and London, 1990.

[20] Skydsgaard, M. A.: It's probably in the air: Medical Meteorology in Denmark, 1810-1875. Med. Hist., 2010, 54(2), 215-236.

[21] Schuh, A.: Biowetter. Wie das Wetter unsere Gesundheit beeinflusst. Verlag C. H. Beck, München, 2007.

[22] International Society of Biometeorology. Available from: http:// biometeorology.org/about_isb/history.cfm

[23] Gyulai, É.: Practice and sciences: Medico-meteorological observations of Borsod county (Hungary) chief medical officer Samuel Benkő (Ephemerides meteorologico-medicae, Vienna, 17941802). [Praxis és tudomány - Benkő Sámuel Borsod vármegyei tiszti fóorvos orvosmeteorológiai naplói (Ephemerides meteorologico-medicae, 1794-1802).] Történelem és Muzeológia - Internetes Folyóirat, Miskolc, 2015, 2(1), 16-45. Available from: http://www.hermuz.hu/hom/images/latogatoinknak/history-journal/pdf/2_2015_1/Gyulai.pdf [Hungarian]

[24] Kamenszky, I.: The health effects of Hungarian air. [A „magyarországi levegő" egészséges létéről általányosan.] Orvosi értekezés. Pest, 1825. Available from: https://goo.gl/Yzemdo [Hungarian]

[25] Benedek, I.: Semmelweis. [Semmelweis.] Gondolat Kiadó, Budapest, 1980. [Hungarian]

[26] Horváth, L., Varga, L., Tél, T.: Weather forecast and their use. [A meteorológiai előrejelzések és alkalmazásaik.] Országos Meteorológiai Szolgálat, Budapest, 2002. [Hungarian]

[27] Kérdó, I.: Weather and vegetative nerve system. [Időjárás és vegetatív idegrendszer.] Időjárás, 1951, 55, 136-144. [Hungarian]

[28] Örményi, I.: We are sensitive. [Érzékenyek vagyunk.] Heves Megyei Népújság, 1975, 26, 9. [Hungarian]

(Boussoussou Nora dr., Budapest, Városmajor u. 68., 1122 e-mail: nora.b.md@gmail.com)

\section{"Omnis ars naturae imitatio est" (Minden művészet a természet utánzása.) \\ Seneca}

